\title{
Literature-Based Character Education
}

\author{
Abdul Hasim ${ }^{1}$, Agus Hamdani ${ }^{2}$, Arief Loekman ${ }^{3}$, Iin Indriyani ${ }^{4}$ \\ \{abdulhasim@institutpendidikan.ac.id ${ }^{1}$, agus@institutpendidikan.ac.id ${ }^{2}$, \\ arieflukman@institutpendidikan.ac.id ${ }^{3}$ \} \\ Institut Pendidikan Indonesia, Jl. Terusan Pahlawan No.83, Garut 44151 1,2,3,4
}

\begin{abstract}
Knowledge lights, The more knowledgeable a student becomes, the more enlightened he will be. The teaching of literature must be able to instill good character values in students. For example, students can be encouraged to explore and identify values of proverbs. These values, once they learn, can be applied in their daily lives. Literature comes in various forms such as fairy tales, proverbs, poetry, prose fiction, and drama. These literature forms, when used for educational purposes, can help students develop their potentials, self-control, personality, intelligence, good character, and other necessary life skills.
\end{abstract}

Keywords: literature teaching, character education.

\section{Introduction}

Character education and national culture are evolving and developing in various subjects, including in Indonesian Language subjects at schools. As a consequence, all subjects are expected to positively contribute to building the students' character.

This is in line with Presidential Decree Number 87 of 2017 relating to strengthening character education. Beforehand, the same regulation was made on May 2, 2010 by former President Susilo Bambang Yodoyono about character education and national cultural values.

Historically, even in the colonial era, character education was incorporated in the education curriculum for prospective teachers that time (elementary school, now). In the late period of Dutch colonization in Indonesia (1940-1942), there were many types of teacher training schools, each of which had different characteristics.

For example, in 1941 there was a Sekolah Desa teacher training course (Cursus Opleiding voor Volks Onderwyzer / OVVO) with two years of education. OVVO students were prepared to teach counting, writing, reading, drawing, singing, and playing (sports, exercises, how to teach), and character / morals for Sekolah Desa students.

In addition, there was Normalschool (NS). This school accomodated students from the People's School (SR). The duration of study was four years, the graduates become Sekolah Desa teachers. Vernacular languages were used as the medium of interaction and this school was specified for male students. The NS curriculum included: Malay, Sundanese/Javanese, writing, educational science, teaching science, life sciences, counting, sound art, sports, Arabic writing, drawing, handwork, agriculture, plant sciences, dutch (elementary), moral, economy, and writing. All students lived in a dormitory. Students who were accepted in the SN were Vervolgschool graduates who had passed the admission test [1]. 
In fact, character education is not something new. It has been a concern for a long time in the world of education. The character-based education already has been long implemented since the colonial curriculum. Contemporarily, the real problem is how character values are embedded in every subject, including in literature subject and internalized so as to materialize noble and civilized individuals. Thus, instilling good characters in students is a necessity in every learning because it is encircled in the national education goals.

The purpose this paper is to present Indonesian language learning, especially literature contents in order to provide enlightenment to students through literature-based character education.

\section{Methods}

Literature learning in Indonesian language subjects in schools is supposed to be concentrated on building students' character. Considering, the material of literature contains character education. In order to find a moral message on a literature work, appropriate analysis methods are necessary. Of the many methods, hermeneutics is the most relevant approach. Hermeneutics is one type of viewpoints that learns about the interpretation of meaning. Thus, a literature text is interpreted to reveal its true meaning.

However, the moral message and values as the essence of literature are not easily found in literature works. They need to be explored with a systematic reading approach. Relying on simply heuristic reading is not satisfactory. Therefore, hermeneutic reading is necessary since it involves reading strategy that implicates interpretation.

\section{Results and discussion}

Literature learning is so extensive ranging from fairy tales, proverbs, poetry, poetry, fiction prose, to drama that students actively develop their potential to have religious spiritual power, self-control, personality, intelligence, noble character, and the necessary skills for himself, for society, nation, and country

Literature learning actually leads to the discovery of moral messages wherein values are very beneficial. Finding moral messages and values are challenging, interpretation is needed so that moral and character values are visibly obtained. Thus, in the semiotic view, language is a sign system, and as a sign, a language denotes meaning. Language as a sign system in literature texts does not only refer to the first order semiotic system, but rather refers to the second level semiotic system. This is in line with the process of reading literature texts that are heuristic and hermeneutic.

For example, from a proverb, if it is explored passionately there will be values of very upright characters. Example: "Air cucuran dari atap jatuhnya ke pelimbahan juga ". The meaning of this proverb is similar to "the apple does not fall far from the tree" in English speaking culture. From the meaning or the interpretation of this proverb, teachers and students are supposed to explore more extensively in order to find the true and substantive values of the teaching material. The meaning of the proverb leads the teachers and students to the discovery that parents are influential models because children almost always imitate their parents.

Exemplary character values must be embedded in students. Given the importance of exemplary, students must understand and imitate exemplary behavior. 
Another example of exploring proverb to instill character, "Kalah jadi abu, menang jadi arang ". That is, 'the result of a fight, win or lose, either way, they will both suffer'. The interpretation is that there is no benefit for people fighting others because there are no such thing as winners from any confrontation. Even the winner will suffer losses, let alone the losing side. Therefore, if students understand the moral message of the proverb, there will be more self-awareness, friendly, loving, and open-minded because it is believed that they will not be providential from any confrontation.

Such a way of learning is important to deliver both challenging and enjoyable atmosphere; for example by giving stimulus to the students in the form of questions to find a number of proverbs, interpret them, and find moral messages or character values from that proverb.

Of course other literature material such as stories (short stories or novels) provide more opportunities to find high moral messages or character values. For example, the fictional prose used as teaching material entitled "Slilit Sang Kiai" by Emha Ainun Nadjib.

Once upon a time, there was a Kiai who was in the grave. This was renowned through the dream of his student. The student met with Pak Kiai in his dream in which the Kiai was held at the door of the heaven. In his dream, Pak Kiai said, "My sins had been forgiven by God, except for one. I did not have the permission of the house owner to take a little of his bamboo to make it a toothpick. That makes me very troubled in the graveyard".

The moral message in the "Slilit Sang Kiai "is very profound. How this underestimated slilit has troubled a Kiai to reach heaven. Therefore, we are not allowed to take others' belongings even if it is the smallest and look-insignificant thing. Thus, based on the story, the character values are honesty and responsibility. Furthermore, it is expected that these values can be applied in the students' daily life (Hasim, in the 2016 National Seminar Proceedings: 5000).

Through a hermeneutic reading of moral messages and character, values will be evidently explored. For example, how we understand and interpret the story of " Slilit Sang Kiai " by Emha Ainun Nadjib which contains a very high moral message, full of meaning, and has noble character values.

Slilit-shaped objects with a very small size also become unexpected disasters if it is not properly acquired. Honesty is something very valuable. This understanding will bring awareness so that it embodies a good students'. Objects that are considered "worthless" even if it is not our right we should refrain ourselves from taking it, let alone doing corruption with the number of billions or even trillions. This is noble character and mental attitude.

Our concern in witnessing the phenomenon of inequality or inequality in this country can actually be found in a literature work. This can be used as literature teaching material to present character values that must be absorbed and internalized by students.

For example, the poem W.S. Rendra is titled "Sajak Ibunda" below.

Maling punya Ibu. Pembunuh punya Ibu./Demikian pula koruptor, tiran facist,/wartawan amplop, dan anggota parlemen yang dibeli,/mereka pun punya Ibu//... Apakah sang anak akan berkata pada ibunya:/Ibu, aku telah menjadi antek modal asing,/yang memproduksi barang-barang yang tidak mengatasi/kemelaratan rakyat//...Ibu, kini aku makin mengerti nilaimu/Kamu adalah tugu kehidupanku,/ yang tidak dibikin-bikin hambar seperti Monas dan/Taman mini.

The metropolitan ecological expression opens our eyes that urban conditions are indeed much tougher; that urban society on the one hand is meticulous and efficient, but on the other hand is often destructive, sadistic, and tends to be boastful. Indeed, it shows the lame glory 
with the real economic conditions (Endraswara, 2016: 87-88). The character values found in the poem include: realistic, that life in the capital is harder; solidarity, that the balance of life is one reason because of ignorance, especially in big cities.

Therefore, the teachers in literature-based education is to facilitate appreciation of literature works (Mustika, in "Literature and Character of Bansgsa Education", 2011: 57). Indeed, when students appreciate literature, novels for example, they will involve cumulative psychological processes, in the form of experiences (Azis and Hasim, 2010: 83). Through such experiences, students are expected to find meaningful values that can be manifested realistically in their daily life.

\section{Conclusion}

The above description can be summarized as follows: First, true character education can be found in all subjects and teaching materials. Second, the teachers must facilitate their students to present character values in each learning material. Third, understanding and appreciation of character values found in literature teaching material should be relevant with the students' understanding and experiences so that they will be able to manifest these values in their daily lives contextually.

Acknowledgement. We gratefully acknowledge that the publication of this research article is financially supported by Institut Pendidikan Indonesia.

\section{References}

[1] Azies, Furqonul, dan Hasim, Abdul. (2010). Menganalisis Fiksi: Sebuah Pengantar. Bogor: Ghalia Indonesia.

[2] Bardy, L. (1985). Ungkapan dan Peribahasa. Klaten: PT Intan.

[3] Damaianti, Vismaia S.(ed) (2011). Riksa Bahasa:Pendidikan Karakter Bahasa dan Sastra Indonesia. Bandung: Rizqi Press.

[4] Endang, Dede. (ed). (2016). Prosiding Seminar Nasional: Pengembangan Literasi Berbasis Kearifan Lokal Pengukuhan Jatidiri Kebudayaan Bangsa. Cirebon: FKIP Unswagati Press.

[5] Endraswara, Suwardi. (2016). Metodologi Penelitian: Ekologi Sastra Konsep, Langkah, dan Penerapan. Yogyakarta: FBS Universitas Negeri Yogyakarta.

[6] Harras, Kholid A. (ed). (2011). Pendidikan Sastra dan Karakter Bangsa. Bandung: Jurdiksastrasia FPBS UPI.

[7] Peraturan Presiden Republik Indonesia, Nomor 87 Tahun 2017. Penguatan Pendidikan Karakter.

[8] Supriadi, Dedi. (2003). Guru di Indonesia: Pendidikan, Pelatihan dan Perjuangan Sejak Zaman Kolonial Hingga Era Reformasi. Jakarta: PT Geranusa Jaya.

[9] Zaimar, Okke Kusuma Sumantri. (2014). Semiotika dalam Analisis Karya Sastra. Depok Indonesia: Komodo Books. 